\title{
Kant's Categorical Imperative and the "Business" of Profit Maximization: The Quest for Service Paradigm
}

\author{
Godwyns Ade Agbude', Joseph Kayode Ogunwede'2, Joy Godwyns-Agbude ${ }^{3}$, \\ Ikedinachi Power Ayodele Wogu' ${ }^{1}$ Excellence-Oluye Nchekwube ${ }^{1}$ \\ ${ }^{1}$ Department of Political Science and International Relations, School of Human Resource Development, \\ College of Leadership Development Studies, Covenant University, Ota, Nigeria \\ ${ }^{2}$ Department of Accountancy, Moshood Abiola Polytechnic, Abeokuta, Nigeria \\ ${ }^{3}$ Charis Center of Leadership Development, Ado-Ekiti, Nigeria \\ Email: agodwins1@yahoo.com, godwyns.agbude@covenantuniversity.edu.ng, unclekfirst@yahoo.com, \\ joygodwyns@yahoo.com, ike.wogu@covenantuniversity.edu.ng, chekwubeugbede@gmail.com
}

Received 11 August 2014; revised 8 September 2014; accepted 10 October 2014

Copyright (C) 2015 by authors and Scientific Research Publishing Inc.

This work is licensed under the Creative Commons Attribution International License (CC BY). http://creativecommons.org/licenses/by/4.0/

(c) (i) Open Access

\begin{abstract}
The discourse in the business world has gone beyond the primary purpose of business. While some scholars would argue that the primary purpose of business is profit maximization, others are of the opinion that business, beyond maximizing profit, exists to promote and enhance the well-being of humanity. Between these two divides, this paper attempts to contribute robustly to this perennial dialogue by interjecting Kant's categorical imperative in pursuing the argument that though profit maximization is essential for business expansion, nonetheless the value of the human persons-both customers and employees-is equally and primarily essentially. Within the scope of this study, the researchers appeal to literature as case studies were presented to underscore the various attempts at making profit and pursuing personal economic benefit by some entrepreneurs without taking cognizance of the importance of the human persons that buy their proposed products. At the end, this paper vehemently appeals to the moral consciousness of entrepreneurs across the globe to integrate moral values to their pursuit of business profit and economic expansion.
\end{abstract}

\section{Keywords}

Kant, Categorical Imperative, Profit Maximization, Morality 


\section{Introduction}

In John Donne's word, "No man is an Island entire of itself; every man is a piece of the continent, a part of the man” [1]. This reveals the interrelation structure of the human person. In other words, man cannot be construed in terms of Lebniz's windowless and uninteracting atoms. Man, as a matter of necessity, needs others to exist.

Aristotle, for instance, long posits that: "He who is unable to live in society or who has no need because he is sufficient for himself, must be either a beast or a god” [2]. This is because man's potentialities can only be developed in the society. The existentialist philosophers are unanimous in their official position about the human person. Central to their presuppositions is the place of man "with-the-others”. For instance, while Descartes asserts the existence of the cogito, "I" as the fundamental being of all existence, Sartre argues that "In the Cogito, one does not discover only oneself but others as well... Thus, the man who attains himself directly through the cogito discovers all others also" [3].

From the argument of the scholars above, we arrived at the importance of the "beings" other than ourselves. Thus, an undeniable relationship arises from our interaction with them. Evidently, business organization is one of such. It is the proof of the dependency nature of the human person. It emerged as one of the groups in the society leveled with the responsibility of catering for man's need.

Matthew A Izibi argues that:

...business organizations are not philanthropic or charitable institutions. However, it is a tool, a ground organized to serve a very specific end and its purpose cannot be disregarded or overemphasized without great harm to the society and individuals [4].

Business organization is intended to serve the good of man. But, the reverse could be the case if not properly guided by rules and regulations codified as moral laws and legal laws. Just as the political organization that is expected to provide a viable society that will serve as a platform for the attainment of the goals and projection for the citizens is being misused by the Machiavellian Prince, so also is the business organization in the hands of immoral entrepreneurs. Business organization has become a tool for the exploitation of man by man. It has become the machinery for the devaluation and destruction of the human person.

\section{Characteristics and Qualities of Business Organization}

1) That business should be profit-oriented. However, this should not be at the expense of the stakeholdersworkers, customers, and competitors.

2) That business should from time to time minimize wastes while making business transaction.

3) That the business organization should offer good career prospect for the employees thereby allowing them to experience.

4) That such business enterprise should reward the employees so as to get them encouraged while they are putting in their very best in their course of service.

5) Respect for the environment where such firm is located, socially, politically, morally and economically, should be an important preoccupation of any business organization. It respects the land. It promotes well-being. It cares for the environment. It is for the good of those in its territory [5].

Business ethics emerged as a distinctive discipline to guide against the violation of any of those qualities above. Man, as an imperfect being, subject to errors, operates within the interface of business organization, must be guided with codes of conduct to avoid destroying the lives of others. In other words, business organization as a man-dominated activity must be guided by rules and regulations to avoid being turned to a tool of man's destruction. Business organization represents a human and technical system designed to produce good or provide varied services to satisfy human needs and wants. This system thus entails choice-making; and according to Barcalow, moral issues arise more fundamentally when the choices people face will affect the well-being of others by either increasing or decreasing it, causing either harm or benefit [6]. With the institutionalizing of business ethics, the various activities of business organizations come under rigorous ethical discussions such as product quality, advertising, pricing, sales techniques, hiring practices, pollution control, business responsibilities to both shareholders and stakeholders.

\section{The Theoretical-Intellectual Foundation of Immoral Business Practices}

Capitalism does require morality, but this cannot be enforced by States (because in some States, political leaders 
who represent the State are themselves notorious capitalists), NGO’s or supra-national institutions. It has to be consciously built into capitalism through deliberate moral education and enlightenment. Kant's Categorical Imperative becomes germane in developing business organizations that will not just explore the inherent loopholes in capitalist economic system to the detriment of others' welfare; but rather will operate within the purview of ethics in enhancing not just the happiness of the shareholders and the business executives but that of the community of human beings whose existence is central to the survival of the business organizations or corporations.

Adams Smith's (1776) classics provide a ground for capitalism, as it were private ownership of corporations (business organization)

Every man is rich or poor according to the degree in which he can afford to enjoy the necessaries, conveniences, and amusements of human life. But after the division of labor has once thoroughly taken place, it is but a very small part of these with which a man's own labor can supply him. The far greater part of them he must derive from the labor of other people, and he must be rich or poor according to the quantity of that labor which he can command, or which he can afford to purchase [7].

From the above, Adam Smith argues that man must be able to foster his economic benefit from the labour of other men. Riches or poverty is a product of how much of others' labour man can galvanize. Thus, the revival of capitalistic ideology stares us in the face. The anachronistic collage underlining capitalism today leads to these three pathologies: the destruction of nature, the widening of inequality, and the failure to promote happiness despite the pretense of doing so [8]. Our discourse on capitalism is a necessity as a way of showing that the present moral devaluation in business practices and the emergence of corporate Machiavellianism is a product of the loophole in capitalism as a global economic system.

Adam Smith (1776), with his metaphor of the Invisible Hand, argues for competitive capitalism in all societies. For him, capitalism enhances the expansion of the wealth of Nations. Every man, like in the Hobbesian Jungle (State of Nature), struggles and strives towards the attainment of personal wealth only to become an agent of the attainment of public wealth and good. This argument for competitive capitalism has resulted into warfare paradigm as against service paradigm in business enterprises. This is because the individual sees this economic arrangement as a license for the pursuit of selfish interests to the detriment of the well-being of others.

According to the warfare paradigm, the overriding objective of the business person is to advance, at all cost, his own individual interests, and thus he engages in a never ending war against his customers in which he tries to get as much as he can from them. Business activities become synonymous with the military battlefield. Businessmen, who operate within the warfare paradigm smile at their customers, bow before them, proclaim that "the client is king" and "the customer is always right", but for them these are only tactics designed to lure their customers into a sense of security in order to better fleece them [9].

John Locke (1690), one of the proponents of Capitalism, argues for unlimited quantity of private property as a natural right of the individual. For him, the earth and all that is therein are given for the support and the comfort of all human beings. Man's labour is the proof of one's ownership of the property. As soon as one annexed out of nature that which was commonly given to all by the Creator, one can claim ownership of such property without being castigated [10]. The idea of Capitalism becomes obvious in Locke's theory as soon as we situate his conception of the purpose of government with his insistence on the importance of private property.

Having established this fundamental right to property, Locke posits his hypothetical justification of a civil society or government. For him, the civil government is the proper remedy for the inconveniences of the state of nature where man is exposed to irregular and uncertain exercise of the power of everyman to punish the transgressor of others, and therein seek the preservation of their property. Thus, the primary purpose of the government is the preservation of the private property of the individuals.

Milton Friedman (1962), in his book Capitalism and Freedom, argues extensively for Capitalism as the only economic system in which the freedom of man could be effectively exercised [11]. He debunked the idea of Socialism as an eco-political system given that it undermines the exercise of individual freedom or liberty due to governmental interventions in the organization of economic activities (market activities). Friedman (1970) argues that businesses (or organizations) are artificial persons and as such could not be said to have responsibilities. Only human persons can have responsibilities. Thus, for him, it is the executives of the organizations or corporations that can be said to have responsibilities. But their responsibility is to maximize profit for the shareholders. The executive is an employee of the owners of the business, and his responsibility is to conduct the business in accordance with their (owners) desires, which generally will be to make as much money as 
possible while conforming to the basic rules of the society. In this sense, profit maximization is taken as the end of every business enterprise. This makes Friedman a real proponent of materialistic capitalism.

Adam Smith's metaphor of the Invisible hand under which man contributes to public interests while striving for his self-interests; Locke's accumulation of private property which has become the basis of individualism in modern Capitalism and Friedman's proposal of profit maximization as the only sole responsibility of business organizations have bequeathed a legacy of materialism on Corporate Managers and individual entrepreneurs. Thus, the present business world is a victim of epidemic of character bankruptcy and moral erosion

\section{Selected Cases in Nigeria}

We present cases of immoral business practices in Nigeria but this does not mean that this is peculiar to Nigeria. All across the globe, there are cases of immoral business practices and corrupt, illegal and immoral entrepreneurs.

\section{Case 1: Illegal Drug Importation}

Some drug importers, in order to evade inspection and detection, can make false declarations about the nature/ content of the products in their containers. They employ unimaginable concealment methods for their nefarious activities. In 2003, a large consignment of a controlled narcotic analgesic was concealed in T-shirts and imported from India via Lagos airport. In 2004, 32 containers of various pharmaceuticals were imported and manifested as motor vehicle spare parts. They were moved to various locations within the ports to avoid detection, NAFDAC inspectors have also found drugs concealed in the inner part of containers containing textiles, candles, shoes, etc. [12].

The above is a report of multiple cases of immoral and illegal business practices in Nigeria in several countries of the world. NAFDAC means National Agency for Food and Drug Administration and Control. It is a body set up by the Nigerian government to regulate food and drug production and distribution in Nigeria.

\section{Case 2: NAFDAC Warns Water Producers on Sharp Practices}

Orhili who gave the warning during a sensitization workshop for packaged water producers in Nigeria stated that in the course of the agency's inspection of water facilities in the country, it has discovered many abnormal practices by packaged water producers which according to him are capable of causing serious health hazards.

He identified the unwholesome practices by these water producers to include, the production of packaged water in unhygienic environment, improper use of water treatment chemicals and inappropriate labeling of products adding that although sanctions have been applied to all these identified cases, the agency will no longer treat offenders with kid gloves [13].

\section{Case 3: N20 Million Worth of Fake and Substandard Textile Products}

The Standards Organization of Nigeria (SON) has seized substandard textile products worth Nigerian naira 20 million across different markets in the country's Lagos city.

According to the head of department of Inspectorate and Compliance of SON, Mr. Bede Obayi, the seizure is a declaration of war against fake textile products circulating in the markets [14].

\section{Case 4: China Imports Fake and Substandard Products to Nigeria}

Frontiers news can authoritatively report that the Standards Organisation of Nigeria (SON) has uncovered over 50 million used and substandard tires in the country with majority of the product in Lagos and Anambra states.

Our correspondents gathered that during a recent raid, SON recovered about five millions fake and used tires from the popular Ladipo spare parts market, in Lagos, and about one million from the busy Onitsha market.

Our correspondents investigations revealed that SON had in late 2011 conducted a survey on some household item and products such as stabilizers, electricity bulbs, children's toys as well as diesel and discovered that over 80 per cent of such products were fake and substandard.

"This is dangerous for a country and if we do not rise up to these challenges and arrest it now, Nigeria is going to pay for it tomorrow. The situation as it is today is sad. You can hardly find any sector of our economy where you do not find fake and substandard products. It is lamentable," the source said.

The source explained further "what we found when we went to petrol stations across the country was incredible. In Lagos, over 50 percent of the diesel in the filling stations was adulterated with kerosene. And when we even measured the quantity they dispense, we also found out in almost all the petrol stations that the consumers were been cheated. It was discovered that twenty liters of fuel they dispense was in actual fact between 17 and 18 liters. This is very unfortunate for us as a nation”. 
Frontiersnews leant that majority of the fake and substandard products examined by SON were mainly from Asia countries with China leading the pack [15].

\section{Case 5: Fake and Substandard Building Materials}

The Head of Administration and Human Capital of the organisation, Mr. Paul Angya who led the exercise said the raid became imperative following the refusal of traders to stop selling fake and sub-standard goods. The exercise which caught traders at Abuja International Building Materials Market and Mararaba Building Materials Market in Nasarawa state unaware saw the organisation sealing off some shops stocked with fake and substandard products [16].

\section{Case 6: The Asian Tigers and Fake Products in Nigeria}

The Asian Tigers are here, but more with substandard and economically wasteful products. The government body responsible for designation, establishment, approval and declaration of standards in respect of materials, commodities, structures and processes, certification of products in commerce and industry, their promotion at national, regional and international levels, throughout Nigeria, and the enforcement of same is the Standards Organisation of Nigeria, SON (Figure 1). The incidences of frequent fire outbreak in homes, industries and offices these days, make the need to check fake wires and bulbs imperative. Door keys and padlocks from China do not last for more than a few weeks; same in the motor spare parts markets, where used parts are now preferred to the so called new ones from China. Today, for almost all items in the market, you have original and fake products displayed side by side, with impunity, and the buyer decides, depending on his choice and purse.

But the worrisome aspect is that the crooks are thriving too much in this business. Some of these men import substandard products from China, paste the name and logo of standard and popular brands on them and sell. Others even open up products like television sets, change the internal components, and sell! Products targeted by fakers cut across items like drugs, tyres, household utensils, phones, electronics, clothing materials, IT equipment, as well as food items like beverages, milk, canned foods, toys, cables, automatic voltage regulators, amongst several others.

Under the current loss estimate of N52bn yearly loss to fake and substandard products auto spare parts appear to be taking the bigger chunk in terms of volume and value of fake products. The sector, according to SON, has an estimated value of N20bn yearly expenditure on fake products [17].

\section{Kant's Categorical Imperative}

Kant differentiates between hypothetical imperative and categorical imperative. The Kantian project in Section of Two of his work, under which the categorical imperative falls is to present the practical faculty of reason from universal rules of determination to the point where the concept of duty as the basis of all moral imperatives is seen to spring. Kant began his moral proposals by opting for universality of morality. According to him, what

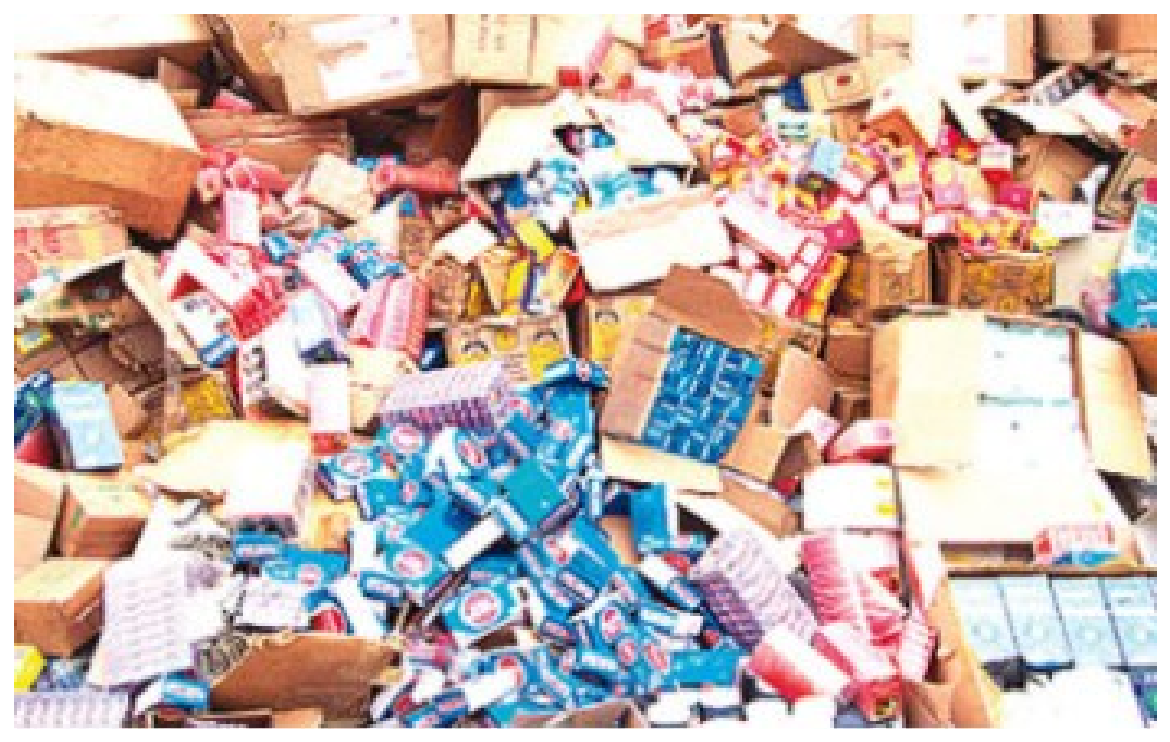

Figure 1. Goods seized by standard organization of Nigeria [SON]. 
determines the morality of an act is its universality. The word "ought" is prior to experience telling us what actions reasons expect all rational being to perform. He points out that moral struggle is an indication of man not being purely rational. Man's nature is thwarted with sentiments, passion, emotions, inclination and natural tendencies. Reason intervenes, telling man what he ought to do. Thus, the moral law is seated in practical reason. According to Kant, everything in nature works according to laws. Rational beings alone have the faculty of acting according to the conception of laws, that is according to principles i.e. have a will. Since the deduction of actions from principles requires reason, the will is nothing but practical reason. If reason infallibly determines the will, then the actions of such a being which are recognized as objectively necessary are subjectively necessary also, i.e. the will is a faculty to choose that only which reason independently of inclination recognizes as practically necessary, i.e. as good [18].

In other words, a rational being is always struggling to do what ought to be done as against just acting from inclinations and self-interest.

The conception of an objective principle, in so far as it is obligatory for a will, is called a common (of reason), and the formula of the command is called imperative.

All imperative are expressed by the word ought (or shall), and thereby indicate the relation of an objective law of reason to a will, which from its subjective constitution is not necessarily determined by it (an obligation) [19].

The imperatives are meant to help man act morally. They are only formulae to express the relation of objective laws of all volition to the subjective imperfection of the will of this or that rational being, e.g. the human will [20].

According to him, all imperative command either hypothetically or categorically. A hypothetical imperative commands us to do that which is a means to an end: thus it is conditional. He further distinguished between problematic hypothetical imperative and assertoric hypothetical imperative. The latter commands one to act in certain ways or do certain things in order to be happy while the former commands one to do certain thing in order to achieve an end. For example, if you want to become a lawyer, you must study law.

On categorical imperative, Kant writes:

...there is an imperative which commands a certain conduct immediately, without having as its condition any other purpose to be attained by it. This imperative is categorical. It concerns not the matter of the action, or its intended result, but its form and the principle of which it is itself a result; and what is essentially good it consists in the mental disposition, let the consequence be what I may. This imperative may be called that of morality [21].

On the contrary, categorical imperative is based on what is expected of rational beings. This imperative is different from hypothetical that is characterized by rules of skill or counsels of prudence. It is categorical because it applies to all rational beings and it is imperative because it is a principle on which we ought to act. From the combination of this two (categorical imperative), Kant posits thus:

When I conceive a hypothetical imperative, in general I do not know beforehand what it will contain until I am given the condition. But when I conceive a categorical imperative, I know at once what it contains. For as the imperative contains besides the law only the necessity that the maxims shall conform to this law, while the law contains no conditions restricting it, there remains nothing but the general statement that the maxim of the action should conform to a universal law, and is the principle on which it ought to act that is an imperative [22].

The distinction between a maxim and a principle in Kantian ethics is that a maxim is a subjective principle on which a person is acting (whether consciously or unconsciously, while a principle is an objective law of morality on which man ought to act.

All rational beings must act with maxims that will be in consonant with the objective principle of moralitycategorical imperative.

The first formulation:

Act only according to that maxim by which you can at the same time will that it should become a universal law.

Immanuel Kant cited this example under to illuminate his postulation of this formulation of the categorical 
imperative.

"Another man finds himself forced by need to borrow money. He well knows that he will not be able to repay it, but he also sees that nothing will be loaned him if he does not firmly promise to repay it at a certain time. He desires to make such a promise, but he has enough conscience to ask himself whether it is not improper and opposed to duty to relieve his distress in such a way. Now, assuming he does decide to do so, the maxim of his action would be as follows: When I believe myself to be in need of money, I will borrow money and promise to repay it, although I know I shall never do so. Now this principle of self-love or of his own benefit may very well be compatible with his whole future welfare, but the question is whether it is right. He changes the pretension of self-love into a universal law and then puts the second question: How would it be if my maxim became a universal law? He immediately sees that it could never hold as a universal law of nature and be consistent with itself; rather it must necessarily contradict itself. For the universality of a law which says that anyone who believes himself to be in need could promise what he pleased with the intention of not fulfilling it would make the promise itself and the end to be accomplished by it impossible; no one would believe what was promised to him but would only laugh at any such assertion as vain pretense”.

Following from his argument that everything in nature works according to the laws of nature, he reframes the categorical imperative to show that it is the law of nature as it relates to human behaviour.

Since the universality of the law according to which effects are produced constitutes what is properly called nature in the most general sense (as to form), that is the existence of things so far as it is determined by general laws, the imperative of duty may be expressed thus: Act as if the maxim of thy action were to become by thy will a universal law of nature [23].

For Kant, the categorical imperative becomes the moral test of all human actions. If a maxim passes the test of the C.I, then the action is morally permissible, but if otherwise, the action is morally forbidden. I opt for deception as a way of life, can I will deception as a universal rule of behaviour? Will I be happy if others use this same principle I endorse against me? If the answer is a no, then such principle of behaviour is fundamentally wrong.

\section{The Second formulation:}

So act as to treat humanity, whether in thine own person or in that of any other, in every case an as end withal, never as means only.

The second formulation is derived from Kant's conception of all rational beings as ends in themselves. Man should not treat another man as a means because in every man there exists the principle of “end-in-themselves”.

If then there is a supreme practical principle or, in respect of the humans will, a categorical imperative, it must be one which, a being drawn from the conception of that which is necessarily an end for everyone because it is an end in itself, constitutes an objective principle of will, and can therefore, serve as a universal practical law [24].

The foundation of this principle is man's conception of himself as an end. This must then become an objective principle of all human actions. It is again the moral law to use man as means to an end only because men are ends in themselves. It is thus against man's nature to be used as mere means to an end no matter how desirable or good the end is. All human activities (or action) must not violate the humanity that is conceived as an end in itself.

Beyond this, Kant argues:

It is not enough that the action does not violate humanity in our own person as an end in itself, it must also harmonize with it. For the ends in himself ought as far as possible to be my ends also, if that conception is to have its full effect with me [25].

The implication of this is that one must not only preserve the humanity in others, one must also act such that one's actions will enhance the humanity of other rational beings. We must add value to the dignity of the other persons. For Kant, even if we cannot add value to the life of any man, we must not at anytime subtract from it.

In his words:

...although, no one should contribute anything to the happiness of others, provided he did not intentionally withdraw anything from it [26]. 
Kant goes on to describe the third formulation thus:

The conception of the will of every rational being as one which must consider itself as giving in all the maxims of its actions from this point of view-this conception leads to another which depends on it and is very fruitful, namely that of a kingdom of ends. A rational being must always regard himself as giving laws either as member or as sovereign in a kingdom of ends which is rendered possible by the freedom of will [27].

The implication of this third formulation is that as human persons, we must recognize the interpersonal relation as members of the same human community. Therefore, at any point one has to take a decision or make a policy, it must be that that recognizes the humanity in others.

All rational beings are united in this kingdom of ends and are bound by common laws. The effect is that we as members of the kingdom of ends must always give universal laws to which we ourselves are subjected to. Acting from duty, for Kant, implies the obligation of every rational being towards the need to enhance their own individual and collective well being.

For Kant, in all our actions, our maxim—-the underlying principle could be view as a legislation for all human beings without contradiction.

\section{The Categorical Imperative and the Corporate World}

Starting from the first formulation, a dealer of fake product should endeavour to universalize the maxim of his behaviour. In other words, he sells fake and killer products to others not minding the effects on their well-being; then he should put himself in the shoes of the buyer and see whether he would appreciate buying something that shortens his life.

In one of the cases above, it was reported that some gas stations mixed kerosene with diesel for their customers. Such entrepreneurs should try to wish that every entrepreneur does the same to them not minding the effects. It is our belief that these immoral entrepreneurs are incapable of universalizing the maxim of their behaviour.

From the second formulation, Kant argues that man should not be treated as mere means to an end; the end being profit maximization in the case of the corporate world. Business owners and investors should not just use their employees as mere means of profit maximization and business expansion. Employees are not supposed to be used as a tool of personal economic advancement of the business owners. In the same line of argument, the host community should not just be seen as a base for personal economic expansion while it suffers pollution, degradation and destruction from the hands of business organizations.

In the same vein, customers offer money for the purchase of products and thus should not just be seen as mere means to profit maximization for the entrepreneurs and their business organizations. Within the purview of the second formulation, we are enjoined by Kant to treat the humanity of all persons as ends in themselves and not means only.

Again Kant argues that "although, no one should contribute anything to the happiness of others, provided he did not intentionally withdraw anything from it...". The implication of this is that if an entrepreneur cannot add any value to the lives of his customers, he should not devalue them in anyway. In other words, if you cannot offer products that would enhance my humanity, do not offer me products that will destroy me. Say in another form, "If you cannot help me; don’t hurt me”.

Kant's third formulation holds that “A rational being must always regard himself as giving laws either as member or as sovereign in a kingdom of ends which is rendered possible by the freedom of will”.

With this, Kant holds that we consider everybody as belonging to the same class of humanity and as such we should seek the benefit of everybody without being self-centered to the detriment of the well-being of others.

With these three formulations, we are appealing to the moral consciousness of business owners to integrate the concept of service into the "business" of profit maximization so that their businesses that ought to be for the good of man does not become the bane of man’s existence.

\section{The Alternative Model: Service Paradigm}

The service paradigm sees its relationship with the customers as that of co-operation.

They do not seek to exploit them but to co-operate with them by making available to them products or services 
which actually solve their problems or help them live richer and more fulfilling lives. These businessmen need money as much as everybody else and therefore they get paid for their efforts, but the crucial point is that they do not think of this payment as the spoils they own from those who were less shrewd or less ruthless than them, but as their fair reward for the value they have created for their customers [28].

In the service paradigm, the sellers (the entrepreneurs) do not see his customers as men and women to be exploited and be consumed but rather as people who need assistance in order to live a better life. Also, the entrepreneur does not try to violate the autonomous nature and the capacity of the buyer to make his/her choices when it comes to purchasing.

One has to determine one's policies on the basis that one's customers are real persons, deserving of one's help and respect, not mere means for the satisfaction of one's desire. But precisely because they deserve this respect one also has to assume that ultimately each customer is the best judge of what is in his or her best interest [29].

The customers are not to be treated as abstract entities but rather as men and women with rational capacity to make choices even though they are to be guided by the sellers, it should be done with the mindset that they deserve to be respected and assisted positively. More so, operating within the confine of the service paradigm entails that the business person must accept that his good-intentioned services have some measure of harmful side effect.

...a conscientious beer brewer who in no way is trying to encourage drunkenness knows perfectly well that, as a matter of statically certainty, some of his customers will get drunk;...some of them will drive in the condition and will cause accidents. But most circumstance, it will still be fair for that brewer to accept those harmful collateral effects of its otherwise legitimate activities [30].

If there are negative fallouts from the services provided, a moral business person will accommodate them as by-products of his activity even though he never set out with such intention. This is the sense of responsibility every business person should demonstrate. The overall argument of service paradigm is that business enterprises must, in all their dealings, engage in activities that enhance the humanity of their customers. Therefore, a human-centered business enterprise provides goods and services which contribute to the well-beings of customers.

...the fact that there is a demand for a product does not automatically justify one in providing it. the product may still be destructive for the user or for society. the general point is that it is ethically wrong (because of its being certainly incompatible with the service paradigm) for one to intend (rather than to accept as a side effect of an activity which has a different and constructive purpose) that one's customer obtain something which he should not obtain [31] (Elegido, 2004: p. 138).

A moral business person with the idea of service paradigm does not just respond to the needs and demands for any product even though he stands the chance of making so much profit from the supply of such product. He investigates the impact of such product on the well-being of the consumer and on the basis of that determines whether to respond to the demand or not. Service paradigm calls for human-centered business practices that do not inhibit the well-being of the customers.

\section{Conclusion}

We believe it is safe to conclude with Kant's possible response to all those who hold profit maximization as paramount to the survival of the "self" and of business enterprises. According to Kant, "It is not enough that the action does not violate humanity in our own person as an end in itself, it must also harmonize with it. For the ends of any subject which is an end in himself ought as far as possible to be my ends also, if that conception is to have its full effect with me” (Kant, 1878/1949: pp. 28-29). In other words, our business actions and inactions must be that which promote the humanity of, not just ourselves, but also of the customers. We must not diminish the happiness of others. For Kant, the new goal of business people must not only be the preservation of humanity but also the promotion of human dignity in oneself and in others. Above all, profit must be pursued with an understanding that profit maximization entails promoting the well-being of others as well. This is the real philosophy of business built on the concept of service paradigm. 


\section{References}

[1] Blackhum, R.M. (1979) The Working Class in Labour Market. Macmillan Press, London, 40.

[2] Aristotle (1962) Politics. Middlex Penguin Class, London, 28.

[3] Sartre, J.P. (1970) L’ Existeialisme est un Humanisme. Nagel, Paris, 66.

[4] Izibi, M.A. (2005) The Responsibilities of Business Organizations: An Ethical Insight. In: Iroegbu, P. and Echekwube, A., Eds., Kpim of Morality Ethics, Heinemann Educational Books, Ibadan, 356-361.

[5] Izibi, M.A. (2005) The Responsibilities of Business Organizations: An Ethical Insight. In: Iroegbu, P. and Echekwube, A., Eds., Kpim of Morality Ethics, Heinemann Educational Books, Ibadan, 356.

[6] Barcalow, E. (1994) Moral Philosophy: Theory and Issues. Wadsworth Publishing Company, Belmont.

[7] Smith, A. (Cannan, E., Ed.) (1776/1937) An Inquiry into the Nature and Causes of the Wealth of Nations. The Modern Library, New York.

[8] Barnes, P. (2006) Capitalism: A Guide to Reclaiming the Commons. Berrett-Koehler Publishers, Inc., San Francisco.

[9] Eleigido, J.M. (2004) Fundamentals of Business Ethics: A Developing Country Perspective. Spectrum Books Ltd., Ibadan.

[10] Locke, J. (1690/1963) An Essay Concerning the True Original Extent and End of Civil Government. In: Somerville, J. and Santom, R.E., Eds., Social and Political Philosophy, Anchor Books Doubleday and Co. Ltd, New York.

[11] Friedman, M. (1962) Capitalism and Freedom. University of Chicago Press, Chicago.

[12] Akunyili, D. (2005) Counterfeit and Substandard Drugs, Nigeria’s Experience: Implications, Challenges, Actions And Recommendations. A Speech Delivered at a Meeting For Key Interest Groups on Health Organized by the World Bank in Washington DC, 10-11 March 2005.

[13] The Tide News (2012) NAFDAC Warns Water Producers on Sharp Practices. http://www.thetidenewsonline.com

[14] Fibre2Fibre (2013) Nigeria’s SON Impounds Fake Textile Products in Lagos. http://www.fibre2fashion.com/news/textile-news/nigeria/newsdetails.aspx?news_id=154965

[15] Frontiersnews (2012) SON Uncovers 50 Million Fake tires in Nigeria Market. http://frontiersnews.com/index.php/news/483-exclusive-report-son-uncovers-50-million-fake-tires-in-nigeria-market

[16] http://www.channelstv.com/2012/07/20/son-raids-two-markets-in-fct-and-nasarawa-state/

[17] https://customerng.wordpress.com/tag/standard-organization-of-nigeria/

[18] Kant, I. (Agbbolt, T.K., Trans.) (1878/1949) Fundamental Principles of the Metaphysics of Morals. Library Liberal Arts, Indianapolis, 17.

[19] Kant, I. (Agbbolt, T.K., Trans.) (1878/1949) Fundamental Principles of the Metaphysics of Morals. Library Liberal Arts, Indianapolis, 17.

[20] Kant, I. (Agbbolt, T.K., Trans.) (1878/1949) Fundamental Principles of the Metaphysics of Morals. Library Liberal Arts, Indianapolis, 18.

[21] Kant, I. (Agbbolt, T.K., Trans.) (1878/1949) Fundamental Principles of the Metaphysics of Morals. Library Liberal Arts, Indianapolis, 19.

[22] Kant, I. (Agbbolt, T.K., Trans.) (1878/1949) Fundamental Principles of the Metaphysics of Morals. Library Liberal Arts, Indianapolis, 22.

[23] Kant, I. (Agbbolt, T.K., Trans.) (1878/1949) Fundamental Principles of the Metaphysics of Morals. Library Liberal Arts, Indianapolis, 23.

[24] Kant, I. (Agbbolt, T.K., Trans.) (1878/1949) Fundamental Principles of the Metaphysics of Morals. Library Liberal Arts, Indianapolis, 23.

[25] Kant, I. (Agbbolt, T.K., Trans.) (1878/1949) Fundamental Principles of the Metaphysics of Morals. Library Liberal Arts, Indianapolis, 28-29.

[26] Kant, I. (Agbbolt, T.K., Trans.) (1878/1949) Fundamental Principles of the Metaphysics of Morals. Library Liberal Arts, Indianapolis, 29.

[27] Kant, I. (Agbbolt, T.K., Trans.) (1878/1949) Fundamental Principles of the Metaphysics of Morals. Library Liberal Arts, Indianapolis, 30-31.

[28] Eleigido, J.M. (2004) Fundamentals of Business Ethics: A Developing Country Perspective. Spectrum Books Ltd, Ibadan, 32-33.

[29] Eleigido, J.M. (2004) Fundamentals of Business Ethics: A Developing Country Perspective. Spectrum Books Ltd, Iba- 
dan, 135.

[30] Eleigido, J.M. (2004) Fundamentals of Business Ethics: A Developing Country Perspective. Spectrum Books Ltd, Ibadan, 135-136.

[31] Eleigido, J.M. (2004) Fundamentals of Business Ethics: A Developing Country Perspective. Spectrum Books Ltd, Ibadan, 138. 
Scientific Research Publishing (SCIRP) is one of the largest Open Access journal publishers. It is currently publishing more than 200 open access, online, peer-reviewed journals covering a wide range of academic disciplines. SCIRP serves the worldwide academic communities and contributes to the progress and application of science with its publication.

Other selected journals from SCIRP are listed as below. Submit your manuscript to us via either submit@scirp.org or Online Submission Portal.
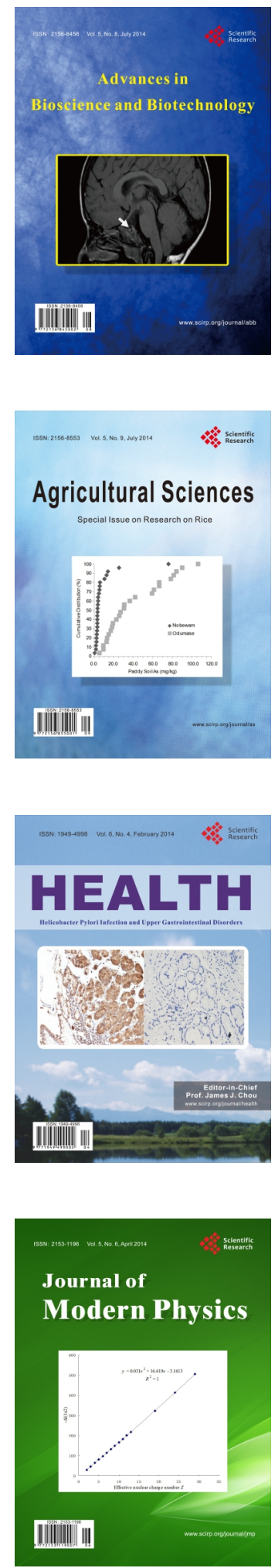
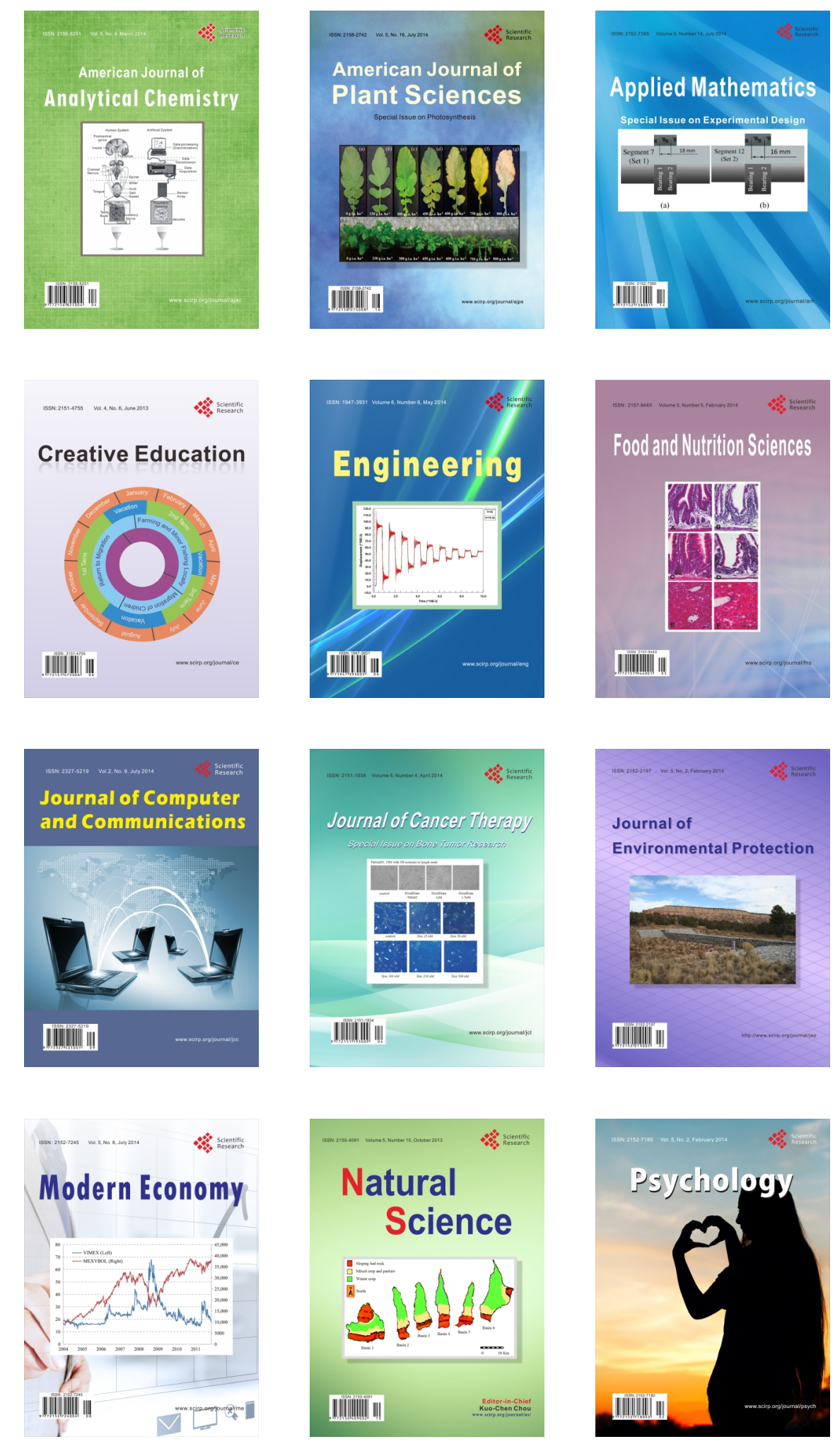